\title{
ANTIOXIDANT ACTIVITY AND INHIBITION OF LIPOXYGENASE ACTIVITY ETHANOL EXTRACT OF ENDOSPERM ARENGA PINNATA (WURMB) MERR.
}

\author{
BERNA ELYA*, NURAINI PUSPITASARI, ANNISA CHAIRANI SUDARMIN
}

Department of Pharmacy, Faculty of Pharmacy, Universitas Indonesia, Depok, Indonesia. E-mail: berna.elya@farmasi.ui.ac.id

Received: 21 April 2017, Revised and Accepted: 13 July 2017

ABSTRACT

Objective: The purpose of this study is to determine the antioxidant activity and the potential inhibition of lipoxygenase activity from sugar palm fruit.

Methods: Antioxidant activity was evaluated by the 2,2-diphenyl-1-picrylhydrazyl (DPPH) and ferric reducing antioxidant power (FRAP) methods. Inhibition of lipoxygenase activity was performed in vitro. Sugar palm fruit was macerated with $95 \%$ ethanol.

Results: The results showed that sugar palm fruit ethanol extract has antioxidant activity when using DPPH method with $\mathrm{EC}_{50}$ of $141.3929 \mu \mathrm{g} / \mathrm{mL}$ and the FRAP method with $\mathrm{EC}_{50}$ of $60.2083 \mu \mathrm{g} / \mathrm{mL}$. Inhibition test of lipoxygenase activity showed inhibitory concentration $50 \%$ value of $71.376 \mu \mathrm{g} / \mathrm{mL}$.

Conclusions: Ethanol extract of endosperm Arenga pinnata has antioxidant activity, as determined using the $\mathrm{DPPH}$ method with $\mathrm{EC}_{50}$ of $141.3929 \mu \mathrm{g} / \mathrm{mL}$ and the FRAP method with $\mathrm{EC}_{50}$ of $60.2083 \mu \mathrm{g} / \mathrm{mL}$.

Keywords: Arenga pinnata, Sugar palm fruit, 2,2-Diphenyl-1-picrylhydrazyl, Ferric reducing antioxidant power, Lipoxygenase.

(C) 2017 The Authors. Published by Innovare AcademicSciences Pvt Ltd. This is an open access article under the CC BY license (http://creativecommons. org/licenses/by/4. 0/) DOI: http://dx.doi.org/10.22159/ajpcr.2017.v10s5.23102

\section{INTRODUCTION}

Unhealthy lifestyles owing to increased consumption of instant foods can lead to the emergence of free radicals, which is exacerbated by cigarettes and pollution [1]. Free radicals are unstable atoms or molecules (having one or more unpaired electrons) that tend to bind to atoms from another molecules, producing abnormal compounds, and initiating chain reactions in the body. The negative effects of free radicals on the body tissues can be overcome by the administration of antioxidants. Free radicals can injure cells or tissues and stimulate inflammation, and if left untreated, this will result in organ damage [2]. Inflammation is a local reaction in the vascular tissue to injuries that shows classical signs, such as redness, heat, pain, and swelling [3]. Inflammation is triggered by several mediators, one of which is leukotrienes. Leukotriene is the synthesis yield of lipoxygenase with arachidonic acid as its substrate. The role of leukotriene in inflammation is to triggers chemotaxis, which causes the migration of leukocytes from blood vessels to the site of injury [4].

Indonesia is a megacenter of world biodiversity. It is estimated that there are approximately 40,000 plant species, of which 30,000 are in the Indonesian archipelago, and 9,600 are medicinal plant species. In the past two decades, there has been an increasing global interest in the use of medicines obtained from the natural resources (traditional medicine), both in developing countries and in developed countries. The World Health Organization states that up to $65 \%$ of the population in developed countries have used traditional medicine with natural ingredients [5].

Palm trees (Arenga pinnata (Wurmb) Merr.) are plants native to Southeast Asia and are mostly found in tropical rainforests and dry forests [6]. Almost all parts of the palm tree are useful for various applications. One of the parts that interest the Indonesian people is the half-cooked endosperm, which is commonly called sugar palm fruit [7]. Sugar palm tree can reduce pain and inflammation in rats, as has been observed from the reduction of writhing in rats (writhing test) induced by glacial acetic acid and Complete Freund's Adjuvant (Dian, 2015). This study was conducted to test whether 95\% sugar palm fruit ethanol extract shows any antioxidant activity (using 2,2-Diphenyl-1-picrylhydrazyl [DPPH] and ferric reducing antioxidant power [FRAP]) and anti-inflammatory activity by inhibiting lipoxygenase activity (in vitro).

\section{METHODS}

\section{Extraction}

Sugar palm fruit was cleaned and crushed before the extraction process using the maceration method. One part was mixed into three parts of $95 \%$ ethanol, and the mixture was subjected to shaking for 5-10 minutes every $8 \mathrm{hrs}$. Then, the macerate was separated and filtered from the dregs. The maceration process was repeated until the macerate was clear. All macerates were collected and evaporated with a vacuum evaporator until a dry extract was obtained.

Antioxidant activity test of sugar palm fruit extract using the DPPH method

Determination of the maximum wavelength of DPPH was performed by adding $1 \mathrm{~mL}$ of $100 \mu \mathrm{g} / \mathrm{mL}$ DPPH solution to $3 \mathrm{ml}$ of pro-ethanol, shaking the mixture for $20 \mathrm{~s}$ using a vortex mixer, and then incubating the mixture at $37^{\circ} \mathrm{C}$ for 30 minutes. The uptake was measured using an ultraviolet (UV)-visible spectrophotometer with wavelength set at $400-800 \mathrm{~nm}$.

\section{Extract/standard antioxidant activity test}

The test solution was prepared by $3 \mathrm{~mL}$ of the sample solution added to $1 \mathrm{~mL}$ DPPH $100 \mu \mathrm{g} / \mathrm{ml}$. The mixture was subjected to shaking for 20 seconds, and then the test solution and control solution were incubated at $37^{\circ} \mathrm{C}$ for 30 minutes. The antioxidant test of the sample was performed by the DPPH method using a UV-visible spectrophotometer. The absorbance of the test solution was measured at the wavelength obtained from the maximum wavelength test.

Calculation of damping percentage and $\mathrm{EC}_{50}$

After absorbance data were obtained, the percentage of extract inhibition to DPPH free radical was calculated. The percentage of inhibition can be calculated using the formula: 


\author{
Absorbance control \\ $\%$ Damping $=\frac{\text {-Absorbance of sample }}{\text { Absorbancecontrol }} \times 100 \%$
}

After the damping percentage was obtained, the equation $y=a+b x$ was determined using a linear regression equation, with the sample concentration as the $\mathrm{x}$-axis and the damping percentage as the $\mathrm{y}$-axis. Then, from the equation $y=a+b x$, we can calculate the value of inhibitory concentration $50 \%\left(\mathrm{IC}_{50}\right)$ by replacing y by 50 in the obtained regression equation.

\section{Antioxidant activity test of sugar palm fruit extract using FRAP method}

The FRAP reagent solution was prepared by taking $10 \mathrm{~mL}$ of a $300 \mathrm{mM}$ acetic acid buffer solution with $\mathrm{pH}$ 3.6, and then adding $1 \mathrm{~mL}$ of $\mathrm{FeCl}_{3} \cdot 6 \mathrm{H}_{2} \mathrm{O}$ solution, and the latter was added to $1 \mathrm{ml}$ of TPTZ solution. In the FRAP testing procedure, two cuvettes were prepared. The first cuvette was filled with $2 \mathrm{~mL}$ of a blank solution $(\mathrm{HCl} 40 \mathrm{M}$ - acetic acid buffer pH 3.61 : 1). The second cuvette was filled with $2 \mathrm{~mL}$ of the FRAP test solution. The FRAP solution was measured at a wavelength of $593 \mathrm{~nm}$

Then, in the sample testing procedure, two cuvettes were prepared. The first cuvette was filled with $1 \mathrm{~mL}$ of blank solution and $1 \mathrm{~mL}$ of ethanol added. The second cuvette was filled with $1 \mathrm{~mL}$ of the FRAP test solution and $1 \mathrm{~mL}$ of baicalein/extract solution. The FRAP solution was measured at $593 \mathrm{~nm}$ wavelength.

\section{Capacity percentage calculation}

After the absorbance data were obtained, the percentage of standard or extracted iron reduction capacity to FRAP was calculated. Capacity percentage can be calculated using the formula:

$\%$ Capacity $=(1-\mathrm{Ts}) \times 100 \%$

Ts $=$ Transmittance

As $=-\log \mathrm{Ts}$

As $=$ Absorbance of FRAP solution + Standard absorbance/extract.

$\mathrm{EC}_{50}$ is calculated using a linear regression equation, with the sample concentration as the $\mathrm{x}$ axis and the capacity percentage as the $\mathrm{y}$-axis. From the equation $\mathrm{y}=\mathrm{a}+\mathrm{bx}$, the value of $\mathrm{EC}_{50}$ can be calculated. Inhibition test of lipoxygenase activity includes (Table 1).

Table 1: Inhibition test of standard/sample lipoxygenase activity

\begin{tabular}{lllll}
\hline Substances & \multicolumn{3}{l}{ Volume $(\mu \mathrm{L})$} & \\
\cline { 2 - 5 } & B & BC & S & SC \\
\hline Borate buffer 0.2 M, pH 9.0 & 1025 & 2000 & 1000 & 1975 \\
Baicalein/extract solution & - & - & 25 & 25 \\
Linoleic acid solution 125 $\mu \mathrm{M}$ & 1000 & 1000 & 1000 & 1000
\end{tabular}

Incubated for 15 minutes at room

temperature

Lipoxygenase solution $10000 \mathrm{U} / \mathrm{mL} 975 \quad-\quad 975$ -

Incubated for 5 minutes at room

temperature

Cold methanol PA

$\begin{array}{llll}1000 & 1000 \quad 1000 \quad 1000\end{array}$

Incubated for 10 minutes at room

temperature

Absorbance was measured at

4000

$\lambda=234 \mathrm{~nm}$ Final volume

*B: Blank, BC: Blank control, S: Sample, SC: Sample control a. Optimization of substrate concentration of linoleic acid Optimization was performed to determine the optimum substrate concentration for testing enzyme activity to achieve maximum reaction rate, but the substrate addition no longer increased the reaction rate [8]. The enzyme unit used in this optimization test was 10,000 units/mL, and a wavelength of $234 \mathrm{~nm}$ was used, according to the method used in the previous research [9] with some modifications.

Then, $1025 \mu \mathrm{L}$ borate buffer saline $(0.2 \mathrm{M}$; pH 9.0) and $1000 \mu \mathrm{L}$ linoleic acid solution with concentrations of $50,75,100,125$, and $175 \mu \mathrm{M}$ were incubated at room temperature for 15 minutes. A $975 \mu \mathrm{L}$ solution of lipoxygenase was added and incubated for 5 minutes at room temperature. Then, $1000 \mu \mathrm{L}$ of cold methanol was added and incubated for 10 minutes. The absorbance of the solution was measured at a wavelength of $234 \mathrm{~nm}$ using a UV-visible spectrophotometer.

b. Stop solution testing

A stop solution test is necessary to determine the solution that can stop the reaction. The test was performed using $\mathrm{HCl}$ (Huang et al., 1991) and cold methanol [10-12].

A total of $1025 \mu \mathrm{L}$ borate buffer saline (0.2 M; pH 9.0) and $1000 \mu \mathrm{L}$ linoleic acid solution of $125 \mu \mathrm{M}$ concentration were incubated at room temperature for 15 minutes. A $975 \mu \mathrm{L}$ lipoxygenase solution was added and incubated for 5 minutes at room temperature, and its absorbance was measured at $234 \mathrm{~nm}$ using a UV-visible spectrophotometer. Subsequently, $1 \mathrm{~mL}$ of the test solution was added and its absorbance was measured at the $5^{\text {th }}, 8^{\text {th }}$, and $10^{\text {th }}$ minute after the test solution was added. The used test solution was $0.2 \mathrm{~N}, 1 \mathrm{~N}$, and $2 \mathrm{NHCl}$, and cold methanol.

c. Inhibition of lipoxygenase ( $\mathrm{IC}_{50}$ )

1. Inhibition test of baicalein lipoxygenase (standard) A total of $1000 \mu \mathrm{L}$ of borate buffer $(0.2 \mathrm{M}, \mathrm{pH} 9.0)$ was added to $25 \mu \mathrm{L}$ of baicalein solution with concentrations of $50,70,120$, 150 , and $180 \mu \mathrm{g} / \mathrm{mL}$, and $1000 \mu \mathrm{L}$ of linoleic acid at $125 \mu \mathrm{M}$, and then incubated for 15 minutes at room temperature. After incubation was performed, $975 \mu \mathrm{L}$ of $10.000 \mathrm{U} / \mathrm{mL}$ lipoxygenase solution was added and incubated for 5 minutes. Subsequently, $1000 \mu \mathrm{L}$ of cold methanol was added and incubated for 10 minutes. The absorbance of the solution was measured at a wavelength of $234 \mathrm{~nm}$ using a UV-visible spectrophotometer.

2. Inhibition test of lipoxygenase extract

A total of $1000 \mu \mathrm{L}$ of borate buffer saline (0.2 M; pH 9.0) was added to a solution of $25 \mu \mathrm{L}$ palm fruit tree samples with concentrations of $200,400,800,1000$, and $1200 \mu \mathrm{g} / \mathrm{mL}$, and $1000 \mu \mathrm{L}$ of linoleic acid solution at $125 \mu \mathrm{M}$, and incubated at room temperature for 15 minutes. A $975 \mu \mathrm{L}$ of lipoxygenase solution was then added and incubated for 5 minutes at room temperature. Furthermore, $1000 \mu \mathrm{L}$ of cold methanol was added and incubated for 10 minutes at room temperature. The absorbance of the solution was measured at a wavelength of $234 \mathrm{~nm}$ using a UV-visible spectrophotometer. The test scheme can be seen in Table 1 .

\section{Calculation of IC $_{50}$}

Inhibition of lipoxygenase activity by extract samples can be determined from the percentage inhibition value and $\mathrm{IC}_{50}$ calculated using the formula:

\section{(AbsorbanceB-BC)}

$\%$ Inhibition $=\frac{-(\text { AbsorbanceS-SC })}{\text { Absorbance }(B-B C)} \times 100 \%$

Description: B: Blank; BC: Blank control; S: Sample; SC: Sample control

The value of $\mathrm{IC}_{50}$ is calculated using a linear regression equation with the sample concentration as the $\mathrm{x}$-axis and percentage inhibition as the $\mathrm{y}$-axis. From the equation $\mathrm{y}=\mathrm{a}+\mathrm{bx}$, the $\mathrm{IC}_{50}$ value can be calculated by replacing y by 50 in the obtained regression equation. 


\section{RESULTS AND DISCUSSION}

Antioxidant activity of sugar palm fruit extract and baicalein using DPPH and FRAP methods

The DPPH method is a simple method for testing antioxidant activity. Sample/standard solution was mixed with the DPPH, and then sample/ standard will give hydrogen atom to the DPPH free radical so that DPPH would be reduced to a stable non-radical (DPPH) form (Molyneux, 2004). Determination of the maximum wavelength of DPPH was performed using $1 \mathrm{~mL}$ of $100 \mathrm{ppm}$ DPPH solution added with $3 \mathrm{~mL}$ of methanol. From the test results, DPPH showed maximum absorption at a wavelength of $516 \mathrm{~nm}$. Furthermore, sample and standard measurements are carried out at these wavelengths.

In the FRAP test, the color of the FRAP reagent solution was initially purplish white. However, after the standard/sample was added, the color of the solution turned into solid blue. This may happen because the $\mathrm{Fe}^{3+}$ complex of tripyridyltriazine $\mathrm{Fe}(\mathrm{TPTZ})^{3+}$ becomes a $\mathrm{Fe}^{2+}, \mathrm{Fe}$ $\left(\right.$ TPTZ $^{2+}$ complex that has a blue color owing to its antioxidants in acidic conditions. In the antioxidant test by DPPH or FRAP, the standard baicalein has a small $\mathrm{EC}_{50}$. In the previous study (Zhou, Xie, and Yan, 2011), the antioxidant test of baicalein was performed by the Trolox method with $\mathrm{EC}_{50}$ of $23.64 \mu \mathrm{g} / \mathrm{mL}$, and the DPPH method yielded an $\mathrm{EC}_{50}$ of $3.676 \mu \mathrm{g} / \mathrm{mL}$. Meanwhile, the $\mathrm{EC}_{50}$ obtained by the FRAP method baicalein was equal to $8.13 \mu \mathrm{g} / \mathrm{mL}$ [13].

Based on linear equation of ethanol extract, $y=0.2764 x+10.919$, the value of the $\mathrm{EC}_{50}$ extract was obtained as $141.3929 \mu \mathrm{g} / \mathrm{mL}$ (Fig. 1), and for baicalein, the standard linear equation, $\mathrm{y}=17.409 \mathrm{x}+2.4041$, yielded an $\mathrm{EC}_{50}$ value of $2.734 \mu \mathrm{g} / \mathrm{mL}$ (Fig. 2). The $\mathrm{EC}_{50}$ value of baicalein standard was obtained from a non-linear equation using the GraphPad Prism 7 application. From the application, the obtained $\mathrm{EC}_{50}$ was $1.965 \mu \mathrm{g} / \mathrm{mL}$.

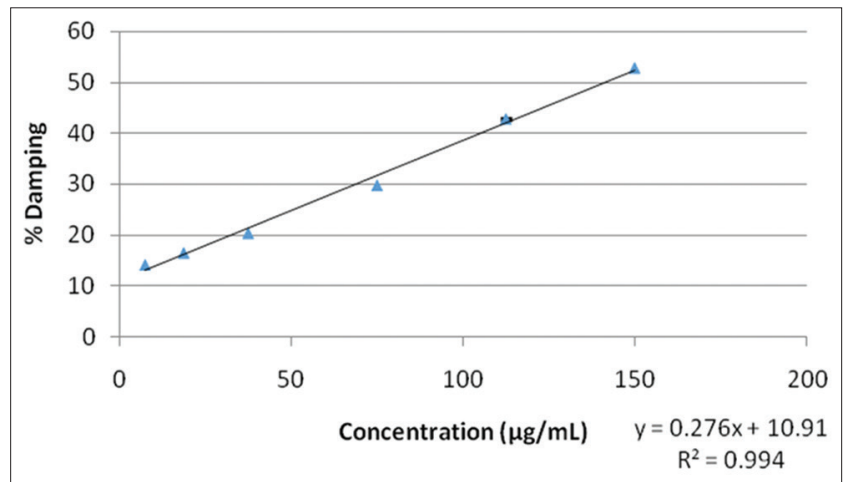

Fig. 1: Curve of the relationship between concentration and 2,2-diphenyl-1-picrylhydrazyl percentage damping by ethanol extract

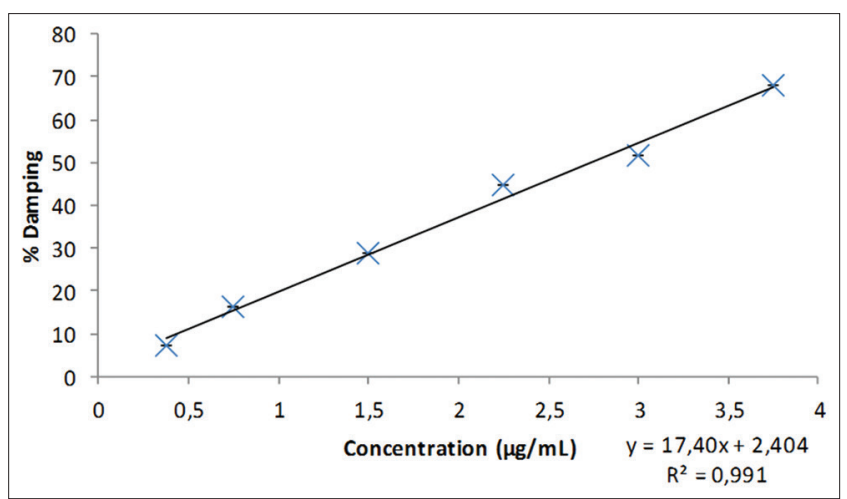

Fig. 2: Curve of the relationship between concentration and 2,2-diphenyl-1-picrylhydrazyl percentage damping by baicalein standard
Based on linear equation of ethanol extract, $y=0.1392 x+41.619$, the value of $\mathrm{EC}_{50}$ extract was obtained as $60.2083 \mu \mathrm{g} / \mathrm{mL}$ (Fig. 3).

\section{Inhibition test of lipoxygenase activity}

Determination of optimum substrate concentration

Before the enzyme inhibitory test was performed, a preliminary enzyme test was conducted. Optimization was done by testing linoleic acid substrate with concentrations of $50,75,100,125$, and $175 \mu \mathrm{M}$ (Fig. 4).

It can be seen at $50-75 \mu \mathrm{M}$ substrate concentration, the absorbance was still increasing. This is because the active side of the enzyme was not fully occupied in this concentration range. Therefore, increasing concentration can still enable generation of a product by the enzyme. At substrate concentrations of 75-125 $\mu \mathrm{M}$, there was a significant increase, whereas at concentrations of $125-175 \mu \mathrm{M}$, there was a slight increase, which showed stability. In this study, the used substrate concentration for linoleic acid was $125 \mu \mathrm{M}$.

\section{Determination of stop solution}

A stop solution test is necessary to determine the solution that can stop the reaction. In this test, enzyme concentration of $10,000 \mu \mathrm{L}$ and substrate concentration of $125 \mu \mathrm{M}$ were used. The tested stop solution was $0.2 \mathrm{~N}, 1 \mathrm{~N}$, and $2 \mathrm{~N} \mathrm{HCl}$, and cold PA methanol.

The results are shown in Fig. 5 reveal that $0.2 \mathrm{~N} \mathrm{HCl}$ cannot resist the formation of the product, as indicated by its falling and rising curves. The results for $1 \mathrm{~N}$ and $2 \mathrm{~N} \mathrm{HCl}$ also reveal that they cannot resist the course of the reaction because there is still an increase. Moreover, the results for cold PA methanol show that the reaction stops. The conclusion from Fig. 6 is that cold PA methanol is effective for stopping the reaction of lipoxygenase.

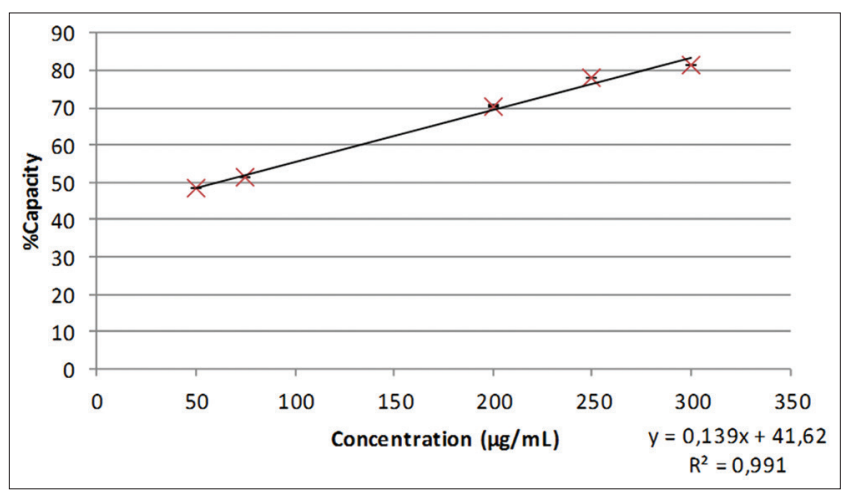

Fig. 3: Curve of relationship between concentration and ferric reducing antioxidant power method percentage damping by ethanol extract

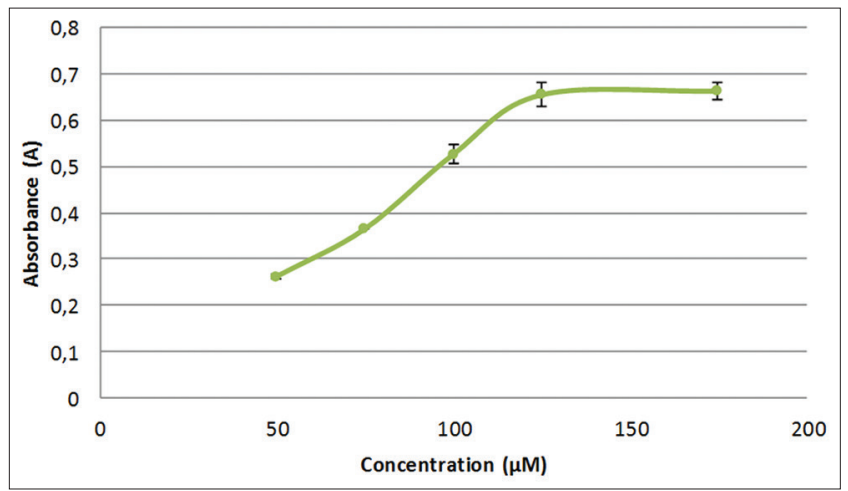

Fig. 4: Optimum substrate concentration graphic 


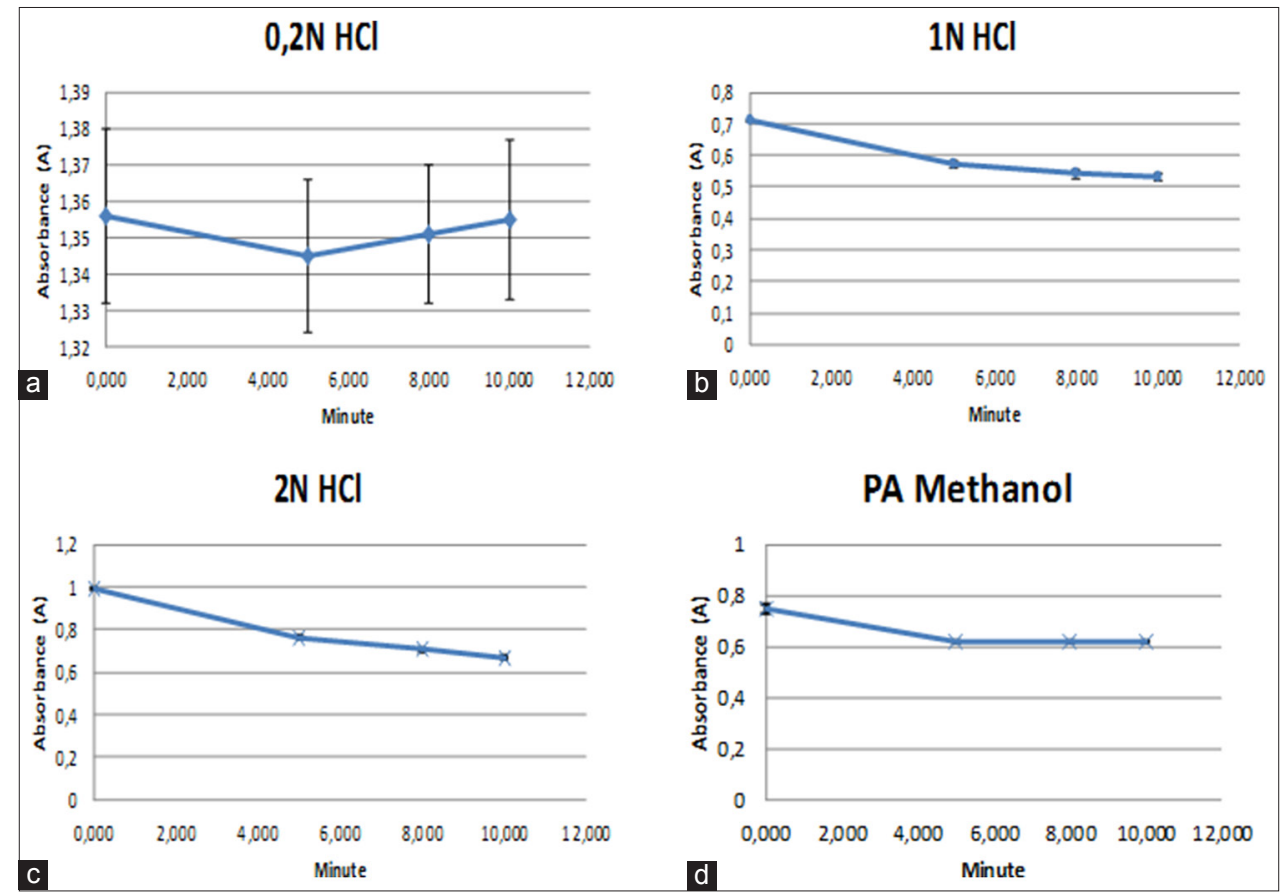

Fig. 5: (a-d) Absorbance of $0.2 \mathrm{NHCl}, 1 \mathrm{NHCl}$, and $2 \mathrm{NHCl}$, and cold PA methanol as stop solution

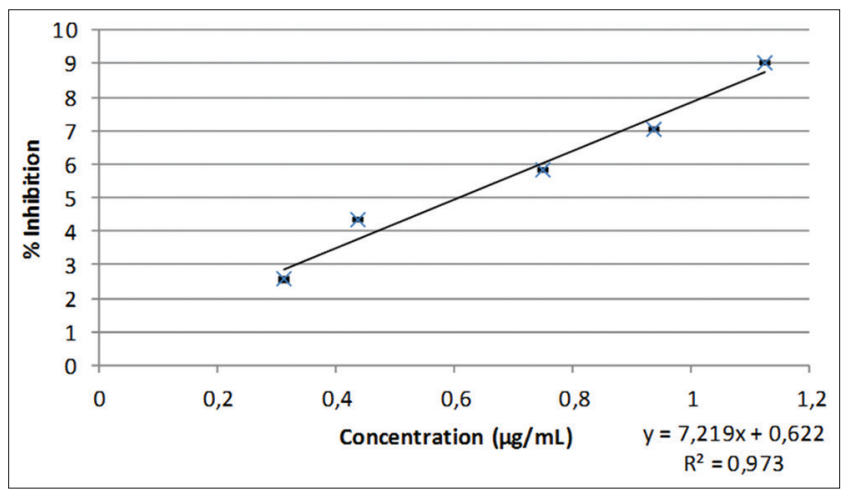

Fig. 6: Curve of lipoxygenase inhibition by baicalein

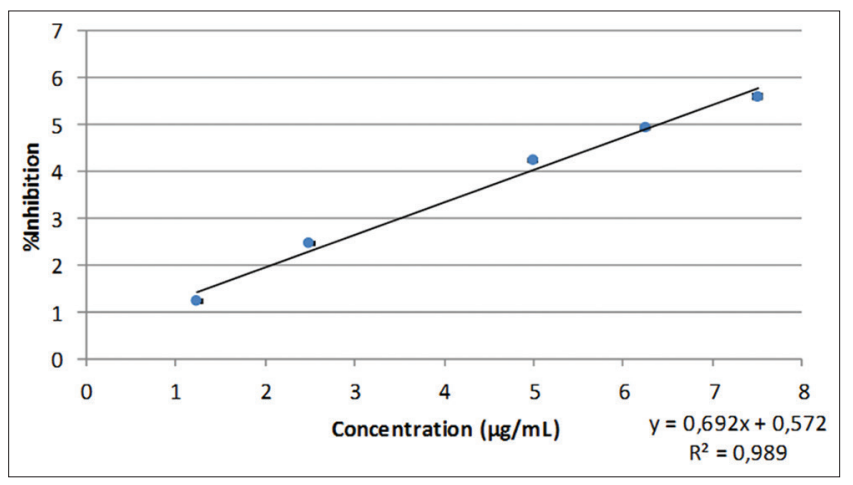

Fig. 7: Curve of lipoxygenase inhibition by extract

Inhibition test of baicalein lipoxygenase ( IC $\left._{50}\right)$

Measurement of $\mathrm{IC}_{50}$ was done by varying the baicalein concentration used as a positive control as follows: $50,70,120,150$, and $180 \mu \mathrm{g} / \mathrm{mL}$. The absorption is measured, and then the percentage of inhibition is calculated. After the percentage of inhibition was obtained, it was plotted into a curve between the concentrations of baicalein and the percentage of inhibition. From the linear equations obtained from the curve, $\mathrm{IC}_{50}$ can be calculated. $\mathrm{IC}_{50}$ is an extract/standard concentration that has inhibitory activity of $50 \%$. This test is done twice (duplo) to compare between the two adjacent and improve the accuracy of the results.

$\mathrm{IC}_{50}$ was obtained by a linear equation in which the value of $\mathrm{y}$ was replaced with 50 , so $x$ value yields the value of $\mathrm{IC}_{50}$. Based on linear equation $y=7.2193 x+0.622$, the baicalein value of IC $\mathrm{C}_{50}$ was obtained as 6.840 (Fig. 6). The smaller the value of the obtained $\mathrm{IC}_{50}$, the better the sample's ability to inhibit the activity of lipoxygenase.

Inhibition test of sugar palm fruit lipoxygenase $\left(\mathrm{IC}_{50}\right)$

After the inhibition test of lipoxygenase to baicalein as the standard, the inhibitory activity test for sugar palm fruit extract was conducted. The test was conducted with various concentrations of the standard ethanol extract solution of $200,400,800,1000$, and $1200 \mu \mathrm{g} / \mathrm{mL}$. The test was done twice (duplo).

Based on linear equation $y=0.6925+0.5723$, the value of extract $\mathrm{IC}_{50}$ was obtained as $71.376 \mu \mathrm{g} / \mathrm{mL}$ (Fig. 7). The extract IC $_{50}$ value is higher than the standard $\mathrm{IC}_{50}$ value.

\section{CONCLUSION}

Ethanol extract of endosperm A. pinnata has antioxidant activity, as determined using the DPPH method with $\mathrm{EC}_{50}$ of $141.3929 \mu \mathrm{g} / \mathrm{mL}$ and the FRAP method with $\mathrm{EC}_{50}$ of $60.2083 \mu \mathrm{g} / \mathrm{mL}$. Inhibition test of the lipoxygenase activity showed $\mathrm{IC}_{50}$ value of $71.376 \mu \mathrm{g} / \mathrm{mL}$. Phytochemical screening of the sugar palm fruit ethanol extract needs to be performed. The fractionation and isolation of the sugar palm fruit ethanol extract need to be conducted in further research.

\section{REFERENCES}

1. Mega IM, Swastini DA. Screening fitokimia dan aktivitas antiradikal bebas ekstrak metanol daun gaharu (Gyrinops versteegii). J Chem 2010;4(2):187-92

2. Closa D, Folch-Puy E. Critical review: Oxygen free radicals and the systemic inflammatory response systemic inflammatory response. Int Union Biochem Mol Biol Life 2004;6(4):185-91.

3. Corwin EJ. Handbook of Pathophysiology. $3^{\text {rd }}$ ed. Philadelphia: Lippincott William \& Wikkins; 2008. 
4. Porth C. Essentials of Pathophysiology: Concepts of Altered Health States. $3^{\text {rd }}$ ed. Philadelphia: Wolters Kluwer Lippincott William \& Wilkins; 2011.

5. Departemen Kesehatan Republik Indonesia. Kebijakan Obat Tradisional Nasional. Jakarta: Departemen Kesehatan Republik Indonesia; 2007.

6. Orwa C, Mutua A, Kindt R, Jamnadass R, Anthony S. Agroforestree Database: A Tree Reference and Selection Guide Version 4.0.; 2009. Available from: http://www.worldagroforestry.org/sites/treedbs/ treedatabases.asp. [Last accessed on 2015 Jun 17].

7. Lempang M. Pohon aren dan manfaat produksinya. Info Teknis EBONI 2012;9:37-54.

8. Murray RK, Bender DA, Botham KM, Kennelly PJ, Rodwell VW, Weil PA. Harper's Illustrated Biochemistry. 28 $8^{\text {th }}$ ed. New York: McGraw-Hill; 2009.

9. Listiyani A, Elya B, Puspitasari N. Activity and lipoxygenase enzyme inhibition assay with total flavonoid assay of Garcinia homroniana pierre stem bark extracts. Pharm J 2017;9(2):276-9.

10. Putri NL, Elya B, Puspitasari N. Antioxidant activity and lipoxygenase inhibition test with total flavonoid content from Garcinia kydia roxburgh leaves extract. Pharm J 2017;9(2):280-4.

11. Hofmann B, Rödl CB, Kahnt AS, Maier TJ, Michel AA, Hoffmann M, et al. Molecular pharmacological profile of a novel thiazolinone-based direct and selective 5-lipoxygenase inhibitor. $\mathrm{Br} \mathrm{J}$ Pharm 2012;165(7):2304-13

12. Chang H, Yang L. Radical-scavenging and rat liver mitochondria lipid peroxidative inhibitory effects of natural flavonoids from traditional medicinal herbs. J Med Plants Res 2012;6(6):997-1006.

13. Chang H, Yang L. Radical-scavenging and rat liver mitochondria lipid peroxidative inhibitory effects of natural flavonoids from traditional medicinal herbs. J Med Plants Res 2012;6(6):997-1006. 